\title{
Evaluation of Some Technologies Developed by the Food Technology Laboratory of the Institute of Agricultural Research for Development: Case of Cocoa, Coffee and Rice
}

\author{
Guemche Sillag Jeanne Irène ${ }^{1}$, Patience Bongse Kari Andoseh ${ }^{2}$, Tchamba Joël ${ }^{1} \&$ Pauline Mounjouenpou $^{2}$ \\ ${ }^{1}$ The University of Jean Paul II Yaounde, Yaounde, Cameroon \\ ${ }^{2}$ Institute of Agricultural Research for Development (IRAD), Yaounde, Cameroon \\ Correspondence: Guemche Sillag Jeanne Irène, The University of Jean Paul II Yaounde, Yaounde, Cameroon. \\ E-mail: irene_jessica2007@yahoo.fr
}

\author{
Received: August 24, 2015 Accepted: September 27, 2015 Online Published: December 15, 2015 \\ doi:10.5539/jas.v8n1p195 URL: http://dx.doi.org/10.5539/jas.v8n1p195
}

\begin{abstract}
The cultivation of plant such as cocoa, coffee and rice is practised by a large number of rural Cameroonian populations. Unfortunately, they are the most suffering of malnutrition, food insecurity and poverty. To improve their livelihoods, the Food Technology Laboratory (FTL) has developed some simple and innovative techniques to transform cocoa, coffee and rice and transferred them to producers. This study aims to evaluate the adoption of those innovations by producers. The survey was conducted in five most important markets in Yaoundé and in one pilot village named Bialanguéna. Data were analysed based on a comparison of the state before and after the acquisition of innovative technologies by producers. Changes observed in the food and economic habits were evaluated. The results show that cocoa products are the most adopted ones. Bialanguena women and Yaounde cocoa producers convert some cocoa beans to cocoa powder and cocoa butter for their therapeutic and nutritive needs. Yaounde cocoa producers go further to commercialize them and generate incomes. This is now their main source of financial income. Therefore, they can afford for food and housing of quality. These innovative technologies could be considered as an alternative to ensure food security in rural area. But the vulgarisation of technologies must continue to reach a large number of producers.
\end{abstract}

Keywords: food insecurity, Food Technology Laboratory, innovative technologies

\section{Introduction}

Agriculture is the backbone of the economy, thus, the base for the development of African countries. Cameroon in particular has made agriculture a development tool. According to the annual statistics of 2013 of the Institute of National Statistics (INS) of Cameroon, agriculture is the main source of employment, since it provides jobs to about $60 \%$ of the working population, mostly in family farms. It plays a major role in generating income in rural areas. Agriculture in Cameroon is characterized by the co-existence of subsistence and commercial farming export-oriented products. Commercial agriculture is characterized by the cultivation of crops such as cocoa, coffee, banana, cotton, rubber and palm oil, etc.

In Cameroon cocoa is produced mainly in the South-western, Littoral, East, Central and South regions. In 2014, Cameroon was ranked the fifth largest world producer of cocoa. Cocoa production involves 400000 families which represent $28 \%$ of the total value of non-petroleum products exported, but participates in the $2 \%$ of the gross domestic product (GDP). In 2012, Cameroon has produced 250,000 tons of cocoa beans and exported 173,794 tons of cocoa beans according to the 2013 annual report of the INS.

Coffee is grown in the western, the North West, the East, the South West regions. In 2012, Cameroon has produced 10000 tons of Arabica coffee and 42,000 tons of Robusta coffee and 5,148 tons of Arabica coffee and 36,436 tons of Robusta coffee were exported according to the 2013 annual report of the INS.

Cocoa and coffee sectors in this country represent $3 \%$ of GDP and $15 \%$ of the GDP primary sector. According to the plan of boosting up the cocoa and coffee sectors by the year 2020, Cameroon expects an annual output of 600,000 tons of cocoa and 160,000 tons of coffee, against the actual production of 206,000 and 23,000 tons respectively. 
The North-West, North and Far North regions abound in the larger basins of rice production. In 2010, these basins occupied an area of $139976 \mathrm{ha}$ and gave a production of 153,078 tons of rice (MINADER/DESA/AGRI-STAT No. 17, July 2012). Rice cultivation in Cameroon is still embryonic. Estimated at around 90,000 tons per year, rice production in Cameroon, marked by a fairly limited local processing, is marketed mostly to foreign countries, especially to neighbouring countries like Nigeria and Tchad (Denis Pompidou Folefack, 2014) whereas national demand is high. To meet this demand, the Cameroon government has resorted to imports. In 2013, Cameroon has mobilized more than 212 billion CFA francs to import more than 819,800 tons of rice, according to statistics from the National Technical Committee of the balance of payments. In 2012, 156.6 billion francs were used to import 552,500 tons of rice according to the same source. This represents an increase of 267,300 tons, showing the important place rice has in the lives of Cameroonians, since it constitutes their major food. But Cameroonian rice is poorly valued and threatened by external competition, which is characterized by multiple facilitations of imports, following the 2008 hunger-strike.

These statistics presented on the cocoa, coffee and rice come from the huge efforts or strategies undertaken by the Cameroonian government after the world global crisis of 1985 and the 2008 food riots. In 1985, the economy of Cameroon goes into recession following the sharp decline in export earnings, falling prices of key commodities namely cocoa and coffee. Between 1985 and 1995, GDP drops by 6.3\% per year (Achancho, 2013) not to mention the abandonment of large rice plantations. According to FAO, these fall in prices of cocoa and coffee also provoked very harmful consequences such as malnutrition, food insecurity and poverty in rural Cameroon. To overcome these problems (malnutrition, food insecurity and poverty in rural areas), the State of Cameroon has set policies including, asking IRAD to develop simple and appropriate technologies for rural areas for food processing. Thus the Food Laboratory Technology IRAD identified several technologies based on cocoa, coffee and rice. These technologies were subsequently transferred to producers in the major basins of productions aiming at encouraging producers of cocoa, coffee and rice in the transformation of part of their crops for their own family consumption. And so, the surplus processed products may be sold. In this way, these producers will be under the lee of malnutrition, food insecurity and poverty. This study aims to evaluate the impact of these technologies of cocoa, coffee and rice on the improvement of the eating habits of farmers. More specifically, to:

$>$ Identify the different food products made from cocoa, coffee and rice developed in the Food Technology Laboratory IRAD.

$>$ Present the different means of transfer and development of these innovations to farmers.

$>$ Analyze the impact of these technologies on dietary habits and the income of farmers.

\section{Methodology}

\subsection{Discussion with FTL Scientists}

A review of the cocoa, coffee and rice innovative products developed and vulgarized by the FTL was done through discussion with scientific staff of the lab. Information's on the processing and the vulgarization (place and tools used) was collected through open and narrative questionnaire.

\subsection{Selection of Study Areas}

\subsubsection{Selection of Yaoundé Market}

The town Yaoundé comprises many areas grouped in 7 divisions Yaoundé I, Yaoundé II, Yaoundé III, Yaoundé IV, Yaoundé V, Yaoundé VI and Yaoundé VII (Figure 1). Each division has a market where majority of sellers of agro-food craft industry sell their products. According to each district, the survey was done in all the seven main markets: Mokolo market, central market, Mvog-Mbi market, Mvog-Ada Melen and Oyom-Abang. 


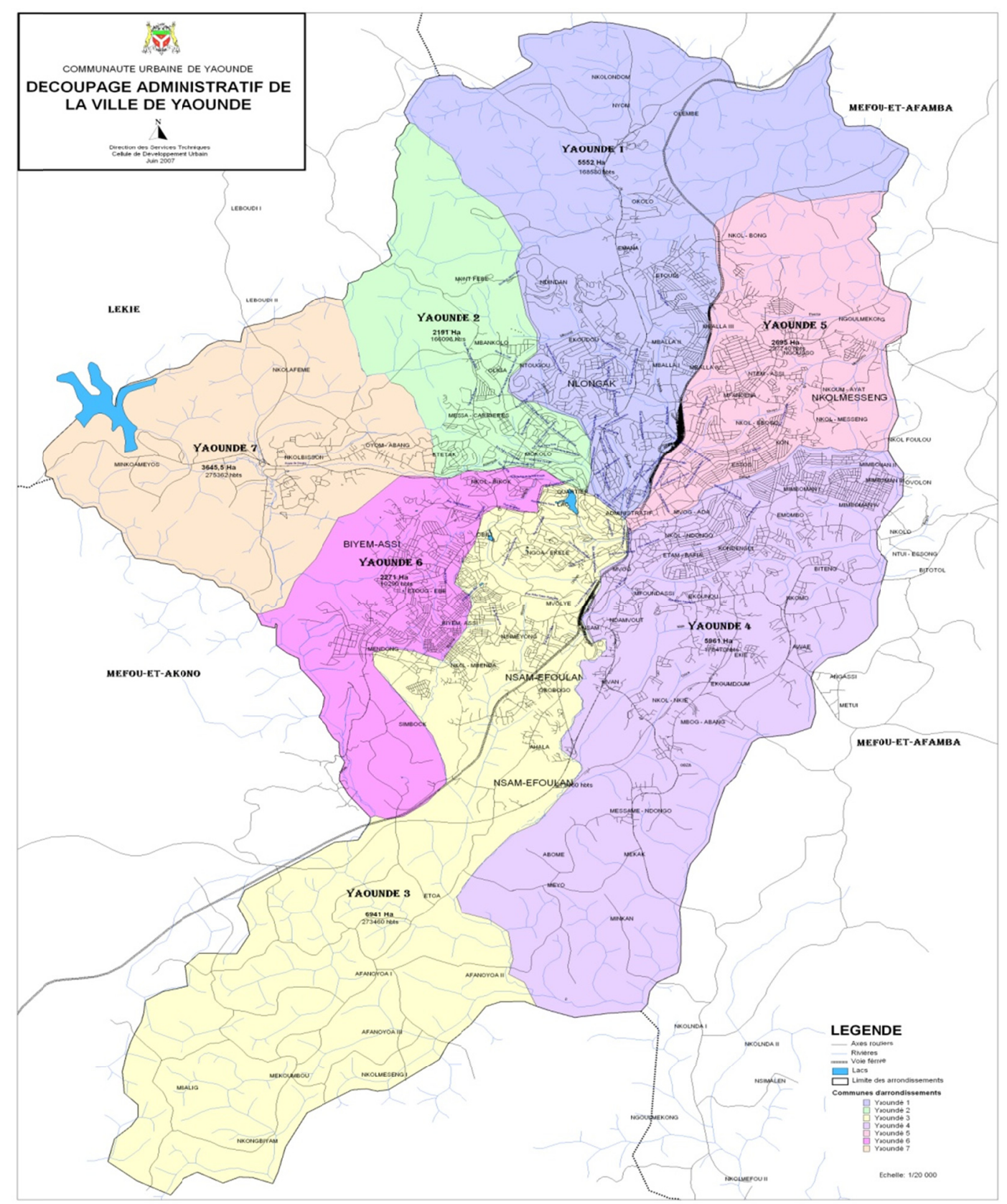

Figure 1. Study area

\subsubsection{Selection of Pilot Village}

The second phase took place in a pilot village. The Pilot village was randomly selected among a number of villages that benefited from the dissemination of research results by FTL. For this study, Bialanguena village, located in the Mbam et-Kim division served as pilot village. The survey was done in the main Bialanguena market name TIKO market.

\subsection{Survey in the Selected Zones}

The survey method used in the field, is the one based on questionnaires. The questionnaire administration method was based on the face to face and self-administration.

The survey was conducted using a questionnaire that contained open, semi-closed and closed questions. These questionnaires focus on the identification of country men and city dwellers, on the level of information on technologies developed by the laboratory of food technology IRAD, the effectiveness and efficiency in practice 
of these technologies by farmers, NGO's members or associations. Level of satisfaction of farmers, their needs and their expectations or desires are also asked. In the village (BIALANGUENA) and city (Yaoundé),

\subsection{Data Analysis}

The data collected on the field were analyzed using the chronologies series or comparisons before/after intervention of the FTL of IRAD. And also based on evaluating criteria, such as: interest for food (producer's self-feeding), revenue (source of financial income), social (improved living conditions), medical (to treat certain diseases).

\section{Results}

\subsection{Main Technologies Developed at the FTL of IRAD}

After discussions with laboratory workers of FTL in IRAD, there are several research technologies that have already been elaborated and transferred to producers (Table 1). Vulgarization of those technologies was done through seminars, scientific days.

Table 1. Main technologies collected at the FTL of IRAD

\begin{tabular}{|c|c|c|c|c|}
\hline & $\begin{array}{l}\text { Processing technologies or } \\
\text { Product }\end{array}$ & $\begin{array}{l}\text { Names of villages, } \\
\text { towns, NGO's and } \\
\text { Association formed }\end{array}$ & $\begin{array}{lcc}\text { Means used to valorise } & \text { or } \\
\text { communicate } & \text { products } & \text { or } \\
\text { technologies } & & \end{array}$ & $\begin{array}{l}\text { Nature of the materials } \\
\text { used for the practice of } \\
\text { these technologies }\end{array}$ \\
\hline Cocoa & $\begin{array}{l}\text { Cocoa butter, soap, Cocoa beans } \\
\text { based-caramel, tea based cocoa } \\
\text { laves, cocoa potash, natural cocoa } \\
\text { powder, rice-wheat biscuits with } \\
\text { cocoa, compost from cocoa shells }\end{array}$ & $\begin{array}{l}\text { Farmers in some villages } \\
\text { in the: Centre region: } \\
\text { Bialanguena, Akoumbeg- } \\
\text { Si, Nseng-Long, South: } \\
\text { Yop, Memian Ngat-Bane, } \\
\text { Biapongo, Bot-maka }\end{array}$ & $\begin{array}{l}\text { Training seminars, expositions, } \\
\text { advocacy Days (scientific days, } \\
\text { days of national technologies, } \\
\text { international days of rural } \\
\text { women ...), communications at } \\
\text { international events, scientific } \\
\text { publications }\end{array}$ & $\begin{array}{l}\text { The household materials } \\
\text { such as pots, traditional } \\
\text { oven, cooking utensils, }\end{array}$ \\
\hline Coffee & $\begin{array}{l}\text { IRAD's ground coffee, coffee } \\
\text { beans-based caramel }\end{array}$ & No village & $\begin{array}{l}\text { Training seminars, expositions, } \\
\text { advocacy Days (scientific days, } \\
\text { days of national technologies, } \\
\text { international days of rural } \\
\text { women ...), communications at } \\
\text { international events, scientific } \\
\text { publications }\end{array}$ & $\begin{array}{l}\text { Sophisticated materials such } \\
\text { as machine to crush coffee, } \\
\text { roaster, the "déparcheur". } \\
\text { But we also use house hold } \\
\text { materials for the manufacture } \\
\text { of coffee caramels. }\end{array}$ \\
\hline Rice & $\begin{array}{l}\text { NDOP rice, simple } \\
\text { wheat-rice-based biscuits, wheat- } \\
\text { rice-based biscuits fortified by } \\
\text { cocoa powder, wheat-rice-based } \\
\text { biscuits fortified by plum powder, } \\
\text { husked rice }\end{array}$ & $\begin{array}{l}\text { No village. Formation of } \\
\text { some rice farmers and } \\
\text { rural women in FTL of } \\
\text { IRAD. }\end{array}$ & & $\begin{array}{l}\text { Some sophisticated materials } \\
\text { such as: husker, the } \\
\text { laundress. But we also have } \\
\text { household materials for the } \\
\text { production of rice biscuits. }\end{array}$ \\
\hline
\end{tabular}

\subsection{The Results from the Surveys Field}

In the Field we collected very pertinent information which reported on elements such as; the degree of satisfaction and difficulties of the respondent as well as, the changes observed after acquiring the technologies of cocoa transformation. These results are recorded on the Tables 2, 3, and 4.

\subsubsection{Feedback of Respondents}

During our survey we collected a lot of satisfactory results. These informations can be obtained from Table 2 below: 
Table 2. Degree of satisfaction of the respondent

\begin{tabular}{|c|c|c|}
\hline Percentage of surveys (\%) & $\begin{array}{l}\text { Survey in } \\
\text { rural areas }\end{array}$ & $\begin{array}{l}\text { Survey in } \\
\text { urban areas }\end{array}$ \\
\hline Respondents cultivating cocoa (with 0.5 to 7 ha) & 73.68 & 28.571 \\
\hline Respondents not cultivating cocoa & 26.32 & 71.428 \\
\hline Surveyed manufacturing and commercialization of cocoa products (cocoa butter ...) & 10.52 & 85.714 \\
\hline Respondents not manufacturing but selling cocoa products (cocoa butter ...) & 0 & 14.285 \\
\hline Respondents trained by the FTL IRAD & 100 & 0 \\
\hline Respondents requesting training for improvement of the transformation process & 100 & 100 \\
\hline Respondents satisfied with processing technologies developed by the FTL IRAD & 100 & 0 \\
\hline Respondents satisfied with cocoa processing technologies & 100 & 100 \\
\hline Respondents satisfied with the economic viability of these technologies & 0 & 100 \\
\hline Surveyed using these technologies to improve their health & 100 & 100 \\
\hline Surveyed using these technologies for food & 100 & 100 \\
\hline $\begin{array}{l}\text { Respondents desiring material assistance (machine to press cocoa butter machine for } \\
\text { pressing cocoa butter...) }\end{array}$ & 100 & 100 \\
\hline Respondents seeking a location for the sale of these products & 100 & 71.428 \\
\hline
\end{tabular}

\subsubsection{The Difficulties of the Respondents.}

The transformers of cocoa whom we came across during our survey raised number difficulties they encounter which is enlisted on the Table 3 below:

Table 3. Difficulties encountered by respondents and proposed solutions

\begin{tabular}{|c|c|}
\hline Problems or difficulties of respondents & Solutions proposed by respondents \\
\hline Lack of materials or cocoa processing infrastructure & $\begin{array}{l}\text { Supply or assistance for the acquisition of certain essential machinery for the } \\
\text { processing of cocoa. }\end{array}$ \\
\hline Problems of Quality of cocoa supplied. & Help in the search of better cocoa quality \\
\hline packaging problems & Help in the manufacture of packaging quality. \\
\hline Location problems or points of sale of cocoa products. & $\begin{array}{l}\text { The state should create shops; kiosks, reserved places for the } \\
\text { commercialization of these products. }\end{array}$ \\
\hline Low acquisition power of the population & Wage increases; creation of jobs for young people. \\
\hline $\begin{array}{l}\text { Bad advertising of cocoa butter produced in the city, } \\
\text { caused by some rural women }\end{array}$ & Advertisements Multiplication of these products. \\
\hline Failure or lack of capital or financial resources & $\begin{array}{l}\text { Accompaniment or supervision by the state structures (PIASSI the } \\
\text { PAJER-U ...) by providing loans or grants to young entrepreneurs-processors } \\
\text { of cocoa. }\end{array}$ \\
\hline $\begin{array}{l}\text { Ignorance or lack of knowledge or lack of interest of } \\
\text { certain people towards cocoa products. }\end{array}$ & $\begin{array}{l}\text { The state should increase evaluation advertisements of cocoa products in } \\
\text { radios and television channels, multiply open days, exhibitions. }\end{array}$ \\
\hline $\begin{array}{l}\text { Electrical power problem for rural women and no mill to } \\
\text { crush in the village. Difficulties to crush cocoa. Women } \\
\text { crush cocoa with manual machines }\end{array}$ & Help in acquiring petrol crushing mills. \\
\hline
\end{tabular}

\subsubsection{The Socio-Economic Changes Brought about by the Transformation Technologies of Cocoa}

When comparing the socio-economic level of the respondents before and after acquisition of these cocoa technologies, we obtained very pertinent informations which is mentioned on the Table 4 below: 
Table 4. Comparison of the state before/after acquisition of cocoa butter Manufacturing Technologies surveyed in BIALANGUENA and Yaoundé

\begin{tabular}{|c|c|c|c|c|}
\hline & \multicolumn{2}{|c|}{ Case of pilot zone: BIALANGUENA } & \multicolumn{2}{|c|}{ For a non-pilot area: Yaounde } \\
\hline & $\begin{array}{l}\text { Before the transfer of the } \\
\text { cocoa butter manufacturing } \\
\text { technologies by the FTL of } \\
\text { IRAD }\end{array}$ & $\begin{array}{l}\text { After the knowledge of the } \\
\text { cocoa butter } \\
\text { manufacturing technology }\end{array}$ & $\begin{array}{l}\text { Before the knowledge } \\
\text { of the cocoa butter } \\
\text { manufacturing } \\
\text { technology }\end{array}$ & $\begin{array}{l}\text { After the knowledge of the } \\
\text { cocoa butter } \\
\text { manufacturing technology }\end{array}$ \\
\hline Supply & $\begin{array}{l}100 \% \text { of respondents say they } \\
\text { could not eat normally when } \\
\text { the price of cocoa was down. } \\
\text { Lack of financial means. }\end{array}$ & $\begin{array}{l}100 \% \text { of respondents say } \\
\text { they process a portion of the } \\
\text { cultivated cocoa for their } \\
\text { food needs. (Cocoa powder } \\
\text { is used at breakfast). And } \\
\text { they increase the quantities } \\
\text { to be processed if the prices } \\
\text { are too low. }\end{array}$ & $\begin{array}{l}100 \% \text { of respondents } \\
\text { say they could not eat } \\
\text { normally. Lack of } \\
\text { financial means. }\end{array}$ & $\begin{array}{l}100 \% \text { of respondents are } \\
\text { now driving towards } \\
\text { self-sustainment with their } \\
\text { products or buy something to } \\
\text { eat. }\end{array}$ \\
\hline $\begin{array}{l}\text { Financial } \\
\text { Income } \\
\text { Source }\end{array}$ & $\begin{array}{l}100 \% \text { of respondents said } \\
\text { they were unemployed and } \\
\text { had no source of financial } \\
\text { income. }\end{array}$ & $\begin{array}{l}100 \% \text { of respondents claim } \\
\text { not to market cocoa butter. } \\
\text { But they plan to do so in the } \\
\text { very near future }\end{array}$ & $\begin{array}{l}100 \% \text { of respondents } \\
\text { said they were } \\
\text { unemployed and had } \\
\text { no source of financial } \\
\text { income. }\end{array}$ & $\begin{array}{l}100 \% \text { of respondents claim } \\
\text { that the sale of the cocoa } \\
\text { butter is economically } \\
\text { profitable and consider it as } \\
\text { their main source of financial } \\
\text { income. }\end{array}$ \\
\hline $\begin{array}{l}\text { Living } \\
\text { conditions }\end{array}$ & $\begin{array}{l}100 \% \text { of respondents said } \\
\text { they lived in miserable life } \\
\text { conditions. }\end{array}$ & $\begin{array}{l}\text { The majority of respondents } \\
\text { say they have improved } \\
\text { their living conditions. For } \\
\text { they are afford for modest } \\
\text { housing. }\end{array}$ & $\begin{array}{l}100 \% \text { of respondents } \\
\text { said they lived in } \\
\text { miserable } \\
\text { conditions. }\end{array}$ & $\begin{array}{l}\text { The majority of respondents } \\
\text { say they have improved their } \\
\text { living conditions. For they } \\
\text { are provided modest } \\
\text { housing. }\end{array}$ \\
\hline $\begin{array}{l}\text { Health } \\
\text { care }\end{array}$ & $\begin{array}{l}100 \% \text { of respondents say they } \\
\text { do not have the means to treat } \\
\text { themselves from illness. }\end{array}$ & $\begin{array}{l}\text { Respondents say they use } \\
\text { cocoa butter as a drug of } \\
\text { some diseases such as } \\
\text { nerves, joint pain (produced } \\
\text { by rural activities)... }\end{array}$ & $\begin{array}{l}100 \% \text { of respondents } \\
\text { say they do not have } \\
\text { means to treat } \\
\text { themselves for illness. }\end{array}$ & $\begin{array}{l}\text { The respondents say they use } \\
\text { cocoa butter as drug for } \\
\text { some diseases such as } \\
\text { nerves, joint pain... }\end{array}$ \\
\hline
\end{tabular}

\section{Discussions}

\subsection{Relevance}

The development of simple technologies for cocoa, coffee and rice processing has as main purpose to fight against malnutrition, food insecurity and poverty in rural areas.

\subsection{Consistency}

These cocoa, coffee and rice processing technologies of the FTL of IRAD are consistent with national and international policies. These simple technologies are in close line with the Cameroonian crop development strategies contained in the ECSD (Strategy Paper for Growth and Jobs 2010-2020) and the document "Development Strategy of the rural sector (SRHR) of 2012" where the government intends to launch a comprehensive program to increase agricultural production to meet not only food needs but also agro-industries. In addition, these technologies were made in collaboration with several organizations, GIC, associations, international projects and programs such as: AFRICA RICE, International Fund for Agricultural Development (IFAD), Special Programme for Food Security (SPFS), National Extension Programme and agricultural research (PNVRA), CONAPROCAM (National Confederation of cocoa and coffee producers in Cameroon).

In comparison with the perspectives outlined in "Diagnosis of the national agricultural research and extension system of Cameroon and capacity building strategy for the dissemination of knowledge and agricultural technologies" (Abdoul et al., 2008), which gives IRAD full collaboration with national and international partners, we can conclude that the FTL has managed the establishment of partnerships with national and international stakeholders.

\subsection{Effectiveness}

BIALANGUENA is an example of a village where the FTL of IRAD has trained women producers of cocoa in the production of cocoa butter and soy milk enriched with cocoa powder. During our raid to BIALANGUENA to assess the impact of these technologies on the fight against malnutrition, food insecurity and poverty of these women, we obtained encouraging results. 100 percent of the surveys are satisfied partly with these technologies. 
The following changes were observed.

> Feeding: BIALANGUENA cocoa producers process cocoa beans to powder and butter for their nutrition.

$>$ Health: cocoa producers use cocoa butter as massage balm to treat joint pain caused by their work in the farm and to treat certain diseases, such as: nerves problems.

D Economy: The BIALANGUENA cocoa producers envisage commercializing cocoa butter. That is why, in their recommendations, these producers request material assistance and cocoa butter marketing location.

Even though the FTL is not directly involved in urban areas, our study shows that the population of Yaoundé appreciates the nutritional and health values of products derived from the processing of cocoa. During our study, we investigated a few people who have been trained by the trainers of MINADER that use these simple technologies for cocoa processing. The following changes were observed:

$>$ Social life: cocoa butter manufacturers are able to rent a modest habitat.

$>$ Economy: cocoa butter manufacturers now have a regular source of financial income. And their purchasing power has increased.

$>$ Feeding: manufacturers now have the financial means to buy the food they need for their nutrition. They also use some of their products for food (cocoa powder for breakfast, cocoa caramel).

$>$ Health: Manufacturers now have financial resources for their health care.

$>$ But note that these resources are still very limited.

According to the survey results obtained in BIALANGUENA and Yaoundé and the participation of the FTL ofIRAD on certain days of agriculture advocacy (Day of Rural Women) and Technology (National Technology Day) and in comparison with goals granted to IRAD in the document "Diagnosis of national agricultural research and extension system of Cameroon and capacity building strategy for the dissemination of knowledge and agricultural technologies" (Abdoul et al., 2008), we can say that the actions and simple cocoa processing technologies developed by FTL of IRAD are effective and have been well received by the audience because they quickly adopted these technologies. But inadequate funding and laboratory staff often helped to lower the efficiency of the search for technologies within the FTL of IRAD and even in other laboratories (Abdoul et al., 2008).

According to Valentine (ACHANCHO, 2013), the local artisanal processing of cocoa has had a particular boom in the production of butter and cocoa powder of which profitability is at least 3 times higher than that of the raw beans. By comparing the results of our study, we can say that the simple cocoa processing technologies developed by the FTL of IRAD produced the expected nutritional or economic changes. These observed changes very well illustrate the contribution or the bringing of simple processing technologies of cocoa to improving food security and reducing malnutrition and poverty in rural Cameroon.

Due to the forecast of employment defined in the ECSD of 2010-2020 and the pre-established tactics in the documents "development strategy of the rural sector (SRHR) in 2012" and "Reduction Strategy of Poverty (SRP)" 2003 we can predict some medium and long term effects of cocoa processing technologies. These are:

$>$ Small and large scale commercialization of these cocoa products by these rural women.

> The very significant reduction of malnutrition, food insecurity and rural poverty.

$>$ Reduction of rural exodus. Youth living in the village will be self-employed by transforming cocoa.

$>$ The creation of small and medium cocoa products manufacturing enterprises.

$>$ The export of these products abroad.

$>$ A very important contribution to GDP and economic growth in Cameroon.

$>$ The reduction of poverty in urban areas.

$>$ The creation of urban (for the recruitment of employed) and rural based jobs (by increasing domestic demand beans and cocoa shells).All these forecasts will be effective, if the Cameroonian government supports these processors and the rural women. For these simple technologies are development opportunities and reducing poverty in rural and urban areas.

\subsection{Efficiency}

The main feature of these technologies is their simplicity because the highlighted commissioning can be done using simple materials or utensils. This gives them a very low production costs. Our survey found that cocoa 
processors in BIALANGUENA and YAOUNDE use kitchen utensils (pots, firewood ...). So, these technologies are efficient because they offer products of nutritional, health virtues and are of good quality at low cost. Moreover, they are accessible to all people of different social classes. Especially the poor whose lack of money is usually a handicap for investing in advanced technologies.

\subsection{Viability or Sustainability}

These technologies are appropriate to the target audience because they adequately meet their expectations. Thus, they provide assistance to the State of Cameroon in the fight against malnutrition, food insecurity and rural poverty. We can summarize the viability of these technologies in the following points:

> Technical Feasibility: 100 percent of women producers of cocoa in BIALANGUENA were trained, and have transformed cocoa after the departure of IRAD's staff. This shows that these technologies are readily accessible to farmers. Moreover, these cocoa processing technologies were not yet in use in various villages that FTL of IRAD assured the transfer of technologies to, like BIALANGUENA. So, in comparison with the visions defined in several documents as "Extension Appliances and agricultural advice in Cameroon: towards the recognition by the agricultural policies of producer organizations and family farms" of (Achancho et al., 2008) advocating the development and technology transfer, we can say that the transfer was almost optimal, as the FTL of IRAD worked with the producers of cocoa, GIC and cocoa processing cooperatives in about fifteen villages in Cameroon. Regarding rice processing technologies, the FTL of IRAD just started the transfer sessions of technologies to farmers, cooperatives and GICs. Finally, very few coffee processing technologies have been developed by the FTL IRAD. We can only list the IRAD ground coffee and coffee-based caramels that are still in full experimentation. There's not been a transfer of coffee processing technologies to farmers, cooperatives and GICs.

In conclusion on the technical nature of the cocoa processing technologies, they are easily exploited by producers of cocoa, rural supervisors, developmental corporations and other developmental actors, because they are simple technologies.

$>$ Socio-Cultural Sustainability: In general, cocoa is the only crop grown by farmers in the villages, so it is of socio-cultural value for these farmers. This socio-cultural influence of cocoa justifies the rapid adoption of simple technologies for cocoa processing by them. Seeing the results obtained in BIALANGUENA, we can say that these technologies are brought into realisation by farmers. And they have prolonged lifetime. Regarding coffee and rice, these two cultures have socio-cultural considerations similar to those of cocoa. This leads us to believe that: coffee and rice growers will very quickly adopt the transformation technologies for coffee and rice during their transfer in major producing basins of coffee and rice. We rely on training and seminars of rice farmers and rural women (during the 19th International Day of Rural Women) at the FTL of IRAD, on the production of rice Biscuits. During these seminars the students were very satisfied and quickly adopted the technology of manufacturing ricebased biscuits.

$>$ Economic and Financial Viability: The particularity of the cocoa, coffee and rice processing technology is their simplicity. And therefore, their method involved is not that costly. Another very significant reason is the use of familiar materials such as pots, artisan kiln (firewood), which are less expensive and are usually family acquired.

In addition, the survival of these technologies cannot be questioned, because of lack of raw materials, for cocoa farmers produce in excess. These are the major exporters of coffee and cocoa. Sometimes these planters are victims of refusal to buy their cocoa or their coffee by Europeans or Americans. Finally, farmers can easily exploit these technologies after the departure of trainers from the FTL of IRAD.

> Environmental Sustainability: The potential environmental impacts of cocoa, coffee and rice processing technologies were anticipated. Some of these technologies are solutions to problems of environmental pollution caused by agriculture. This is the case of the manufacture of potassium ash or compost, soap from cocoa shells. (Mounjouenpou et al., 2012). It is well known that the cocoa shell is a source of environmental pollution. Its valorization is a way to fight against environmental pollution and also contribute to better management of natural resources.

> Sustainability in Relation to Gender: Compared with the principles of the Quebec Association of International Cooperation Organizations (AQOCI) defined in "Results-Based Management (RBM) approach in connection with Gender and Development (GAD)" in 2008, these cocoa, coffee and rice processing technologies follow the principles of gender and development (GAD), because they are easily applied by women, men, different age groups, some disables, all classes, all ethnic group. 


\subsection{Visibility}

The FTL of IRAD works closely with the extension service and the General office of IRAD to popularize these technologies. Communication tools and awareness are used: website: www.irad-cameroun.org; Scientific Days (JERSIC), National Technology Days; expositions, training seminars, communications at international events, scientific publications.

\subsection{Innovation}

Researchers at the FTL of IRAD are the pioneers to make and to transfer these simple cocoa processing technologies to farmers in Cameroon's villages (BIALANGUENACINA, AKOMONYADA...) high cocoa culture. These technologies were non-existent in most of the villages where the said laboratory trained.

\section{Conclusion}

To summarize all these, the acquisition of cocoa processing technologies by some people in the Centre Region has produced the desired changes; Such as the production of butter and cocoa powder by women producers of cocoa in BIALANGUENA for their food and health care. Also, the production and commercialization of cocoa butter and other cocoa products by some Yaoundé dwellers, to meet their food need, health and welfare. Even though not transferred to areas of large productions of coffee and rice, products of rice and coffee processing technologies have already achieved encouraging appreciations at seminars and expositions at FTL of IRAD. In light of these observations, we can say that these simple cocoa, coffee and rice processing technologies, are opportunities to be seized in the fight against malnutrition, food insecurity and urban poverty especially in rural areas. For this, there is an urgent need to boost both the local production (which is currently low), of rice, cocoa and coffee and producer's education to transform part of their crops to market the products obtained. All this will help to strengthen food security, the fight against malnutrition and poverty. To do this, strong actions need to be taken concretely on the ground such as a better organization of cocoa, coffee and rice sectors; an improvement in the production of cocoa and coffee, improving productivity and competitiveness of local rice; amplification of researches for cocoa, coffee and rice processing technologies and their transfer in major cocoa, coffee and rice production areas. Finally, a further institutional support and funding of the players in the various sectors is capital. Not to mention the establishment of monitoring and evaluation systems of different actions, in order to know if the planned objectives have been achieved.

\section{References}

Abdoul, A. S., Moise, H., \& Akoulong, C. J. (2008). Diagnosis National agricultural research and extension system of Cameroon and capacity building strategy for the dissemination of knowledge and agricultural technologies (p. 27).

ACDIC. (2011). Statistical data of imports of goods and staples 2004 to 2011. ACDIC, Yaoundé, Cameroon.

Achancho, V. (2008). Review and analysis of national investment strategies and agricultural policies in Central Africa: the case of Cameroon. In A. Elbehri (Ed.), Rebuild the food potential of West Africa. FAO/IFA.

Anonymous. (2008). Results-Based Management (RBM) approach in connection with the Gender and Development (GAD) in 2008.

Denis, P. F. (2014). Booster local rice production to strengthen food security in northern Cameroon. J. Appl. Biosci.

Development of Rural Sector Strategy (RSDS). (2006). Summary of Component Agriculture and Rural Development. Republic of Cameroon.

ECAM. (2008). Trends, profile and determinants of poverty in Cameroon between 2001 to 2007. National Statistics Institute, Yaoundé, Cameroon.

Gerard, F., Dorin, B., Beliere, J. F., Dairra, A., Keita, S. M., \& Dury, S. (2008). Soaring international food prices whether or disaster for the poorest people. MOISA Working paper No. 8, CIRAD, Montpellier.

IFAD. (2010). Formulation document of the project Support to the Development of Agricultural Sectors (PAFDA). Republic of Cameroon.

MINADER. (2002). Support Project Professionalization of farmers' organizations of Cameroon (APOPC), Results and impact.

MINADER. (2004). Study of the Evaluation of the results and impact of the Project for the National Agricultural Extension and Research Programmed (PNVRA).

MINADER. (2009). National Development Strategy of rice in Cameroon (p. 21). Milling III. Yaounde. 
MINEPAT. (2008). Self-sufficiency and food security in Cameroon: An analysis based on the soaring prices of food staples (p. 55). MINEPAT Steering Committee rural development. Yaoundé, Cameroon.

NSI. (2013). Statistical Yearbook 2013 of the NSI (National Statistics Institute) of Cameroon.

PRS. (2003). Strategy for Poverty Reduction (PRS) in 2003. Republic of Cameroon.

SRHR. (2012). Strategy development of the rural sector (SRHR) in 2012. Republic of Cameroon.

World Bank. (2009). Document project to support agricultural competitiveness (PACA). Republic of Cameroon.

\section{Copyrights}

Copyright for this article is retained by the author(s), with first publication rights granted to the journal.

This is an open-access article distributed under the terms and conditions of the Creative Commons Attribution license (http://creativecommons.org/licenses/by/3.0/). 